\title{
PENGEMBANGAN TES PENILAIAN KETERAMPILAN PROSES SAINS PADA PEMBELAJARAN IPA SISWA KELAS IV SD
}

\author{
N.K.D.Muliani ${ }^{1}$, Sariyasa ${ }^{2}$, I.G.Margunayasa ${ }^{3}$ \\ ${ }^{123}$ Program Studi Pendidikan Dasar \\ Universitas Pendidikan Ganesha \\ Singaraja, Indonesia \\ e-mail: dewi.muliani@undiksha.ac.id ${ }^{1}$, sariyasa@undiksha.ac.id ${ }^{2}$, \\ igede.margunayasa@undiksha.ac.id ${ }^{3}$
}

\begin{abstract}
Abstrak
Penelitian dan pengembangan ini didasarkan pada kebutuhan tes penilaian untuk mengukur keterampilan proses sains siswa. Penelitian ini bertujuan untuk mengetahui tes penilaian keterampilan proses sains pada pembelajaran IPA siswa kelas IV SD yang valid dan reliabel serta untuk mengetahui karakteristik tes penilaian yang dikembangkan. Penelitian ini menggunakan metode $R \& D$ dengan model 4D yang dibatasi hanya menggunakan tiga tahapan yaitu tahap define, design, dan develop. Tahap disseminate tidak dilaksanakan karena pandemic Covid-19. Tes penilaian yang dikembangkan berbentuk soal uraian yang kemudian divalidasi oleh tim ahli. Berdasarkan hasil validasi ahli terhadap aspek materi, konstruksi, dan bahasa, tes dinyatakan valid dengan kategori sangat baik. Validitas isi dengan analisis $C V R$ memperoleh nilai $C V R=1,00$ sehingga 20 butir soal dinyatakan valid. Selanjutnya tes diujicobakan pada siswa sebanyak 50 orang. Hasil uji coba selanjutnya dianalisis untuk mengetahui validitas butir dan reliabilitas tes. Hasil validitas butir dengan rumus korelasi product moment memperoleh semua butir soal memiliki $r_{\text {hitung }}>r_{\text {tabel }}$ dengan $r_{\text {tabel }}$ sebesar 0,28 sehingga semua butir soal dinyatakan valid. Hasil uji reliabilitas tes diperoleh nilai $r_{1.1}$ sebesar 0,93 berada pada kategori derajat reliabilitas sangat tinggi. Jadi tes penilaian keterampilan proses sains yang dikembangkan valid dan reliabel untuk dapat digunakan dalam mengukur keterampilan proses sains siswa.
\end{abstract}

Kata Kunci : Keterampilan Proses Sains; Pembelajaran IPA; Tes Penilaian

\begin{abstract}
This research and development is based on the need for assessment tests to measure students' science process skills. This research aims to determine valid and reliable assessment tests of science process skills in science learning for fourth grade students and to determine the characteristics of the assessment tests developed. This study uses the R\&D method with the 4D model which is limited to only three stages, namely the define, design, and develop stages. The disseminate stage was not carried out due to the Covid-19 pandemic. The assessment test developed was in the form of description questions which were then validated by a team of experts. Based on the results of expert validation on the material, construction, and language aspects, the test was valid in the very good category. Content validity with CVR analysis resulted a CVR value $=1.00$ so that 20 items were categorized valid. Furthermore, the test was tried out on 50 students. The test results were then analyzed to determine the validity of the items and the reliability of the test. The validity results of the items with the product moment correlation formula obtained that all items had $r_{\text {count }}>r_{\text {table }}$ with $r_{\text {table }}$ of 0.28 hence all items were categorized valid. Furthermore, the reliability test results obtained $r_{1.1}$ value of 0.93 which is in the category of excellent reliability degrees. Finally, the science process skills assessment test was valid and reliable to be used in measuring students' science process skills.
\end{abstract}

Keywords : Assessment Test; Science Process Skills; Science Learning 


\section{PENDAHULUAN}

Dalam Undang-Undang RI No.20 Tahun 2003 Tentang Sisdiknas, Bab 1 Pasal 1 Ayat 1 menyatakan bahwa pendidikan adalah usaha sadar dan terencana untuk mewujudkan suasana belajar dan proses pembelajaran agar siswa secara aktif mengembangkan potensi dirinya untuk memiliki kekuatan spiritual keagamaan, pengendalian diri, kepribadian, kecerdasan, akhlak mulia, serta keterampilan yang diperlukan dirinya, masyarakat, bangsa dan Negara. Dalam hal ini pendidik memiliki peranan untuk mewujudkan sebuah pembelajaran yang dapat membentuk karakter siswa, watak, peradaban dan mengembangkan potensi melalui proses pembelajaran guna tercapainya tujuan pendidikan. Untuk mengetahui berhasil tidaknya pencapaian tujuan pendidikan bergantung pada proses pembelajaran yang dialami siswa. Indikator keberhasilan suatu proses pembelajaran adalah tercapainya ketuntasan belajar siswa yang dicerminkan oleh nilai kognitif, nilai afektif (spiritual maupun sosial), dan nilai psikomotorik. Hal-hal tersebut menjadi rasionalisasi pengembangan Kurikulum 2013.

Kurikulum 2013 menitik beratkan pada optimalisasi kompetensi sikap, pengetahuan dan keterampilan. Semua kompetensi tersebut saling berkaitan satu sama lain yang dituangkan dalam kompetensi dasar (KD) dan dikemas dalam pembelajaran tematik (Juanda, 2019). Menurut Pamuji (2018) pembelajaran tematik merupakan pendekatan pembelajaran yang mengintegrasikan kompetensi dari berbagai mata pelajaran ke dalam berbagai tema, sehingga kurikulum pembelajaran menjadi lebih sederhana serta siswa mampu memperoleh keterampilan dan pengetahuan secara utuh. Sesuai dengan Permendikbud nomor 22 tahun 2016 tentang standar proses pendidikan, pembelajaran tematik pada kurikulum 2013 menggunakan pendekatan saintifik.

Salah satu muatan pembelajaran pada kurikulum 2013 di SD/MI yaitu IPA. Pembelajaran IPA ditekankan pada pemberian pengalaman langsung untuk mengembangkan kompetensi agar siswa menjelajahi dan memahami alam sekitar secara ilmiah (BSNP, 2006). Dalam pembelajaran IPA, pendekatan saintifik dilaksanakan lebih kompleks dari mata pelajaran lainnya. Agar siswa dapat melaksanakan proses pembelajaran saintifik, mereka haruslah memiliki suatu kemampuan yang dimiliki saintis berupa kemampuan penemuan yang didapat melalui proses percobaan. Menurut Lusidawaty\&Zikri (2020) menyatakan bahwa peran guru dalam pembelajaran yang menekankan pada proses hanyalah sebagai pembimbing dan pengarah, sedangkan yang menggerakkan proses tersebut adalah siswa sendiri. Penguasaan proses tersebut memerlukan keterampilan ilmiah yang tercakup dalam keterampilan proses sains.

Keterampilan proses sains merupakan keseluruhan keterampilan ilmiah yang terarah baik kognitif maupun psikomotorik yang dapat digunakan untuk menemukan suatu konsep atau prinsip atau teori, untuk mengembangkan konsep yang telah ada sebelumnya atau untuk melakukan penyangkalan terhadap suatu penemuan (Trianto, 2010). Dalam proses pembelajaran IPA, seorang guru diharapkan dapat merancang proses pembelajaran yang dapat melatih keterampilan proses sains siswa. Menurut Funks dkk (dalam Citrawathi, 2016) menyatakan keterampilan proses sains perlu dibelajarkan karena dapat mengembangkan pengetahuan serta keterampilan. Untuk mengukur keterampilan proses sains siswa dalam pembelajaran IPA maka perlu diadakan evaluasi. Menurut Mania (2014) evaluasi adalah suatu proses penilaian yang dilakukan untuk mengetahui tingkat keberhasilan dari suatu program pendidikan, pengajaran ataupun pelatihan yang sebelumnya telah dilaksanakan. Hasil evaluasi dapat diperoleh dengan melakukan suatu penilaian.

Saat ini instrumen penilaian keterampilan proses sains pada proses pembelajaran IPA hanya berupa lembar observasi yang kadang kala memberikan celah untuk guru menilai siswa secara 
subyektif (Suryani dkk, 2015). Penilaian keterampilan proses sains dengan instrumen unjuk kerja dan observasi belum optimal dan efektif penggunaannya karena dalam penerapannya guru mengalami keterbatasan dalam hal pengamatan mengingat banyaknya jumlah siswa yang diamati serta waktu yang tidak mencukupi dalam pengamatan (Azizah, 2017). Sedangkan penilaian dari proses pembelajaran yang diberikan guru hanya mengukur pemahaman konsep siswa saja tanpa melatih dan mengembangkan keterampilan proses sains yang dimiliki siswa (Suryani dkk, 2015). Menurut Wati, dkk (2015) menyatakan bahwa keterampilan proses sains siswa di Indonesia masih relatif rendah, salah satu faktor penyebabnya adalah penilaian yang digunakan cenderung menuntut siswa untuk menghafal materi dan tidak menilai keterampilan proses sains siswa. Sementara itu kajian PISA pada tahun 2018 menyatakan bahwa Indonesia menempati peringkat ke-74 dari 79 negara di bidang sains dengan skor 396 jauh dibawah rata-rata skor OECD yaitu sebesar 489 (OECD:2018). Begitu juga hasil TIMSS 2015 menyatakan bahwa dalam bidang IPA (Sains), Indonesia memperoleh skor sebesar 397 poin berada pada urutan 45 dari 48 negara. Hal ini menjadi salah satu gambaran kemampuan sains siswa di Indonesia masih rendah. Salah satu faktor penyebabnya antara lain karena siswa di Indonesia kurang terlatih dalam menyelesaikan soal-soal yang mengukur penguasaan konsep sekaligus keterampilan proses, dan masalah yang dihadapi oleh guru adalah kemampuan guru dalam mengembangkan instrumen tersebut masih kurang (Budiman dan Jailani, 2014).

Hal tersebut diperkuat dari hasil wawancara dengan beberapa guru di SD Gugus VIII I Gusti Ketut Pudja yang menyatakan bahwa dalam proses pembalajaran IPA guru belum mengukur kemampuan keterampilan proses sains siswa ketika melaksanakan evaluasi karena keterbatasan waktu yang dimiliki. Keterampilan proses sains siswa diamati dengan lembar observasi. Guru merasa sangat disibukkan dengan mengamati siswanya dalam waktu yang bersamaan sehingga pada lembar observasi yang dicatat hanya siswa yang sangat aktif dan tidak aktif saja. Hal ini membuat penilaian keterampilan proses sains siswa menjadi tidak merata. Sementara untuk penilaian proses pembelajaran, sebagian besar guru tidak menyusun sendiri soal yang akan diujikan, tetapi mengambil soal-soal dari buku ajar atau LKS yang digunakan dalam proses pembelajaran sehari-hari dan arsip soal dari tahun sebelumnya. Sehingga soal tidak mengalami perubahan yang berarti dari tahun ke tahun. Beberapa guru sudah ada yang menyusun soal sendiri namun tidak membuat kisi-kisi soal sehingga ketercapaian tujuan yang diukur menjadi tidak jelas. Tes penilaian yang diberikan kepada siswa hanya mengukur pemahaman konsep yang berupa hafalan saja tanpa memperhatikan keterampilan proses sains yang dimiliki siswa. Hal tersebut dikarenakan guru belum melakukan perencanaan yang matang untuk mengukur keterampilan proses sains siswa.

Kondisi tersebut belum sesuai dengan kurikulum 2013, bahwa yang perlu dinilai bukan hanya pemahaman konsep siswa terhadap suatu materi tetapi juga kemampuan soft skill. Sebagai salah satu hasil belajar IPA yang sangat penting, kemampuan siswa pada aspek keterampilan proses sains haruslah mendapat perhatian serius. Oleh karena itu, mengevaluasi keterampilan proses sains merupakan usaha untuk membangun pemahaman siswa terhadap materi-materi IPA, maka perlu adanya instrumen tes yang dibuat untuk mengukur keterampilan proses sains siswa pada pembelajaran IPA. Menurut Arikunto (2010) tes adalah serentetan pertanyaan atau latihan serta alat lain yang digunakan untuk mengukur keterampilan, pengetahuan intelegensi, kemampuan atau bakat yang dimiliki oleh individu atau kelompok. Melalui pertanyaan-pertanyaan guru dapat merangsang, membimbing dan menilai keterampilan proses sains serta penguasaan pengetahuan siswa (Adnyana \& Citrawathi, 2017). 
Beberapa penelitian pengembangan tes penilaian keterampilan proses sains menunjukkan bahwa tes yang dikembangkan layak digunakan untuk mengukur keterampilan proses sains siswa. Penelitian Azizah (2017) menyatakan pada penelitiannya bahwa tes keterampilan proses sains pada materi pesawat sederhana dinyatakan valid dan berkualitas untuk digunakan dalam penilaian hasil belajar. Nilai seluruh aspek validasi instrumen yang divalidasi didapat nilai rata-rata sebesar 3,6 dengan kategori sangat baik atau langsung dapat digunakan. Nilai person reliability yang diperoleh peneliti adalah 0,76 dengan kategori cukup, sedangkan nilai item reliability yang diperoleh adalah 0,99 dengan kategori istimewa. Tingkat kesukaran butir soal instrumen yang dikembangkan terbagi dalam empat tingkatan yaitu 3 soal sangat sulit, 4 soal sulit, 4 soal mudah, dan 2 soal sangat mudah. Perbedaan kategori dalam satu aspek keterampilan proses sains dikarenakan dalam satu aspek keterampilan proses sains dibuat beberapa bentuk soal yang akan di jawab siswa. Penelitian senada yang dilakukan IImi (2016) menyatakan bahwa tes keterampilan proses sains yang dikembangkan dinyatakan layak digunakan sebagai instrumen penilaian untuk mengukur keterampilan proses sains siswa secara spesifik pada materi rangkaian arus searah. Keseluruhan aspek yang dinilai dinyatakan layak yaitu aspek kesesuaian materi dengan tujuan pengukuran, aspek kesesuaian butir instrumen dengan indikator dan bahasa yang digunakan tidak menimbulkan makna ganda.

Kedua pengembangan tes tersebut diperuntukkan bagi siswa sekolah menengah yang sudah mengaplikasikan keterampilan proses lanjutan. Untuk mengukur keterampilan proses sains dasar diperlukan perangkat tes yang berbeda. Berdasarkan hal tersebut, dilakukan penelitian pengembangan yang bertujuan untuk mengetahui tes penilaian keterampilan proses sains pada pembelajaran IPA siswa kelas IV SD yang valid dan reliabel dan untuk mengetahui karakteristik tes penilaian keterampilan proses sains pada pembelajaran IPA siswa kelas IV SD yang dikembangkan.

\section{METODE}

Metode penelitian yang digunakan adalah metode penelitian dan pengembangan atau Research and Development (R\&D). Produk yang dikembangkan yaitu tes penilaian keterampilan proses sains pada pembelajaran IPA siswa kelas IV SD Gugus VIII I Gusti Ketut Pudja. Penelitian ini menggunakan model pengembangan yang mengikuti alur dari Thiagarajan (1974), yaitu menggunakan model 4D yang terdiri dari empat tahapan pengembangan yaitu tahap pendefinisian (define), tahap perancangan (design), tahap pengembangan (develop), dan tahap penyebaran (disseminate). Namun tahap penyebaran (disseminate) tidak dapat dilaksanakan karena kondisi dan situasi pandemi Covid-19.

Pada tahap define dilakukan analisis kebutuhan pengembangan yang disesuaikan dengan keperluan serta model penelitian dan pengembangan yang cocok dalam mengembangkan suatu produk. Pada tahap ini terdapat beberapa langkah yaitu analisis kurikulum, analisis materi, analisis siswa dan spesifikasi tujuan pembelajaran. Tahap Design merupakan tahap perancangan sebuah instrumen tes. Terdapat beberapa langkah pada tahap ini yaitu penyusunan kisi-kisi dan mengimplementasikan kisi-kisi menjadi butir-butir soal keterampilan proses sains serta menyusun pedoman penskoran yang bertujuan untuk mempermudah proses penilaian atau penskoran. Pada tahap ini menghasilkan versi awal draft 1 yang selanjutnya di revisi terlebih dahulu oleh pembimbing dan selanjutnya disempurnakan melalui proses pada tahapan pengembangan.

$$
\text { Tahap Develop, tahap }
$$
pengembangan ini dilakukan dengan beberapa proses, yaitu validasi oleh ahli dan praktisi untuk mengetahui kelemahan atau kekurangan yang terdapat pada produk yang kemudian kekurangan tersebut akan diperbaiki sehingga menjadi draf II. Data yang diperoleh dari hasil 
validasi ahli terhadap tes penilaian keterampilan proses sains dianalisis menggunakan analisis Content Validity Ratio (CVR) menurut Lawshe (1975), formula ini digunakan karena dalam penelitian melibatkan lima validator dengan rumus sebagai berikut:

$$
\mathrm{CVR}=\frac{n e-\frac{N}{2}}{\frac{N}{2}}
$$

(Lawshe (1975)

Selanjutnya peneliti melakukan analisis validitas isi dari aspek materi, aspek konstruksi, dan aspek bahasa. Pada aspek materi soal harus sesuai dengan indikator, setiap pertanyaan harus diberikan batasan jawaban yang diharapkan, materi yang ditanyakan harus sesuai dengan tujuan pengukuran, dan materi yang ditanyakan harus sesuai dengan jenjang dan jenis sekolah atau tingkat kelas. Pada aspek konstruksi soal menggunakan kata tanya atau perintah yang menuntut jawaban terurai, ada petunjuk yang jelas tentang cara mengerjakan soal, setiap soal harus ada pedoman penskorannya, dan tabel, gambar, grafik, peta, atau yang sejenisnya disajikan dengan jelas, terbaca, dan berfungsi. Pada aspek bahasa rumusan kalimat soal harus komunikatif, menggunakan bahasa Indonesia yang baik dan benar, tidak menimbulkan penafsiran ganda, tidak menggunakan bahasa yang berlaku setempat/tabu, dan tidak mengandung kata/ungkapan yang menyinggung perasaan siswa. Validitas dari aspek materi, konstruksi dan bahasa di analisis menggunakan rumus skala lima sebagai berikut

Tabel 1. Skala Lima Penilaian Tes

\begin{tabular}{cl}
\hline \multicolumn{1}{c}{ Rentang Skor } & \multicolumn{1}{c}{ Klasifikasi / Predikat } \\
\hline$M_{i}+1,5 S D_{i} \leq \bar{X} \leq M_{i}+3,0 S D_{i}$ & Sangat baik/Sangat tinggi \\
$M_{i}+0,5 S D_{i} \leq \bar{X}<M_{i}+1,5 S_{i}$ & Baik/Tinggi \\
$M_{i}-0,5 S D_{i} \leq \bar{X}<M_{i}+0,5 S D_{i}$ & Cukup/Sedang \\
$M_{i}-1,5 S D_{i} \leq \bar{X}<M_{i}-0,5 S D_{i}$ & Tidak baik/Rendah \\
$M_{i}-3,0 S D_{i} \leq \bar{X}<M_{i}-1,5 S D_{i}$ & Sangat tidak baik/Sangat rendah \\
\hline
\end{tabular}

(Sumber: dimodifikasi dari Koyan, 2012)

Setelah memperoleh hasil validasi isi dari tes penilaian keterampilan proses sains maka draf II yang telah direvisi akan diujicobakan kepada 50 orang siswa dan diukurlah tingkat validitas butir soal dan reliabilitas dari tes tersebut.

Penentuan validitas butir soal digunakan rumus korelasi product moment sebagai berikut.

$$
r_{x y}=\frac{N \sum X Y-\sum X \sum Y}{\sqrt{\left(N \sum X^{2}\right.}-\left(\sum X\right)^{2}\left(N \sum Y^{2}-\left(\sum Y\right)^{2}\right)}
$$

(Sugiyono, 2009)

Sedangkan analisis reliabilitas tes penilaian keterampilan proses sains menggunakan rumus Alpha Cronbach. Dengan rumus sebagai berikut.

$$
\mathrm{r}_{1.1}=\left(\frac{k}{k-1}\right)\left(1-\frac{\Sigma \sigma_{b}{ }^{2}}{\sigma_{t}{ }^{2}}\right)
$$

(Candiasa, 2010)

Tes penilaian keterampilan proses sains yang telah diukur validitas dan reliabilitasnya akan direduksi dengan membuang soal yang dinyatakan tidak valid. Sehingga tes hanya menyisakan soal yang valid dan reliabel yang akan menjadi produk final.

\section{HASIL DAN PEMBAHASAN}

Hasil dari penelitian pengembangan ini berupa tes penilaian berbentuk soal uraian yang digunakan untuk menilai keterampilan proses sains siswa pada pembelajaran IPA. Pengembangan tes penilaian keterampilan proses sains terdiri dari 3 tahapan, yaitu tahap pendefenisian (define), tahap perencanaan (design), tahap pengembangan (develop) dijelaskan sebagai berikut:

\section{Tahap Pendefinisian (Define)}

Tahap ini bertujuan untuk menetapkan dan mendefinisikan syaratsyarat pembelajaran diawal dengan menganalisis kebutuhan yang dilakukan dengan mengkaji kurikulum, pemetaan KI, 
$\mathrm{KD}$, analisis konsep, silabus, serta RPP mengenai materi IPA teori sifat-sifat cahaya, dan mengkaji tujuan dari batasan materi yang dikembangkan.

Berdasarkan wawancara dengan guru kelas IV di SD Gugus VIII I Gusti Ketut Pudja, penilaian keterampilan proses sains yang selama ini dilakukan kurang perencanaan yang matang yaitu mengembangkan instrumen penilaian yang mengukur keterampilan proses sains siswa secara spesifik. Penilaian yang dilakukan oleh guru hanya mengukur pemahaman konsep saja bukan keterampilan proses sains siswa. Hal ini disebabkan karena belum ada tes yang dapat mengukur pemahaman konsep sekaligus keterampilan proses sains siswa karena guru terbatas kemampuannya dalam mengembangkan instrumen tersebut.

Dalam kurikulum 2013 yang perlu dinilai bukan hanya pemahaman konsep siswa terhadap suatu materi tetapi juga kemampuan soft skill, salah satunya yaitu keterampilan proses sains yang diangkat sebagai bentuk keterampilan yang perlu dikembangkan, digunakan, dan diukur ketercapaiannya. Untuk melaksanakan penilaian keterampilan proses sains diperlukan instrumen pembelajaran yang sesuai. Oleh karena itu, perlu dikembangkan suatu instrumen pembelajaran yang baik. Instrumen pembelajaran yang dikembangkan dalam penelitian ini adalah tes keterampilan proses sains.

Selanjutnya peneliti melakukan wawancara untuk mengetahui kegiatan dan karakteristik dari siswa yang sesuai dengan rancangan dan pengembangan bahan pembelajaran. Dari proses wawancara didapatkan bahwa pengalaman yang dimiliki siswa hanya sebatas mendengar keterampilan proses sains. Sedangkan untuk pengalaman siswa mengerjakan soal-soal yang berhubungan dengan keterampilan proses sains masih kurang. Hal ini tidak terlepas dari peranan guru dalam pelaksanaan pembelajaran.

Berdasarkan analisis materi didapat beberapa materi IPA yang akan diajarkan di kelas IV. Adapun kompetensi dasar untuk pokok bahasan sifat-sifat cahaya yaitu Kompetensi Dasar : 3.7 Menerapkan sifat-sifat cahaya dan keterkaitannya dengan indera penglihatan

Dari analisis kurikulum, siswa dan materi diatas, disimpulkan bahwa setiap SD yang digunakan sebagai sampel penelitian sudah menggunakan kurikulum 2013, sehingga sudah menerapkan keterampilan proses sains. Namun guru belum pernah secara khusus memberikan soal untuk mengukur keterampilan proses sains siswa. Berdasarkan hal tersebut, peneliti menemukan guru dan siswa sangat membutuhkan instrumen tes penilaian keterampilan proses sains.

\section{Tahap Perancangan (Design)}

Pada tahap design (perancangan) memiliki tujuan untuk mendesain instrumen-instrumen yang diperlukan selama penelitian dan mendesain rancangan produk yang hendak dikembangkan. Terdapat beberapa langkah pada tahap ini yaitu penyusunan kisi-kisi, dan penyusunan tes, kunci jawaban serta pedoman penskoran. Dasar penyusunan kisi-kisi tes penilaian keterampilan proses sains adalah analisis materi dan spesifikasi tujuan pembelajaran. Kisi-kisi tes penilaian keterampilan proses sains dapat dilihat pada Tabel 2.

Tabel 2. Kisi-Kisi Tes Penilaian Keterampilan Proses Sains

\begin{tabular}{llll}
\hline Aspek KPS & Indikator KPS & Nomor Soal & $\begin{array}{c}\text { Jumlah } \\
\text { Soal }\end{array}$ \\
\hline Mengamati & $\begin{array}{l}\text { Menggunakan alat indera untuk } \\
\text { mengidentifikasi tiruan objek yang } \\
\text { diamati dan mengumpulkan fakta yang } \\
\text { relevan mengenai sifat-sifat cahaya dan } \\
\text { alat optic }\end{array}$ & $1,2,7,12,195$ & \\
& & & \\
\hline
\end{tabular}




\begin{tabular}{llcc}
\hline Aspek KPS & Indikator KPS & Nomor Soal & $\begin{array}{c}\text { Jumlah } \\
\text { Soal }\end{array}$ \\
\hline Mengklasifikasikan & $\begin{array}{l}\text { Mencari perbedaan/ persamaan dan } \\
\text { mengelompokkan objek yang diamati } \\
\text { mengenai sifat-sifat cahaya dan alat optik }\end{array}$ & $5,10,14,16$ & 4 \\
Memprediksi & $\begin{array}{l}\text { Mengemukakan apa yang mungkin } \\
\text { terjadi pada keadaan yang belum diamati } \\
\text { mengenai sifat-sifat cahaya dan alat } \\
\text { optik }\end{array}$ & $3,6,8$ & 3 \\
Menyimpulkan & $\begin{array}{l}\text { Menyimpulkan dan memberikan } \\
\text { penjelasan berdasarkan hasil } \\
\text { pengamatan mengenai sifat-sifat cahaya }\end{array}$ & $4,9,18,20$ & 4 \\
Mengkomunikasikan & $\begin{array}{l}\text { Mendiskusikan dan membahas hasil } \\
\text { pengamatan mengenai sifat-sifat cahaya }\end{array}$ & $11,13,15,17$ & 4 \\
Jumlah Soal & 20 & & \\
\hline
\end{tabular}

Berdasarkan kisi-kisi aspek KPS dan indikator yang telah dibuat, rincian soal yang dikembangkan yaitu sebagai berikut: Butir soal nomor 1 mengukur keterampilan mengamati pada materi sifat cahaya dapat merambat lurus. Pada soal ini siswa diarahkan untuk mengamati gambar arah rambat cahaya lilin melalui tiga buah lubang karton. Siswa diminta untuk mengamati apakah cahaya lilin akan terlihat pada lubang karton terakhir. Butir soal nomor 2 mengukur keterampilan mengamati pada materi sifat cahaya menembus benda bening. Pada soal ini siswa diminta untuk mengamati sebuah gambar percobaan cahaya senter yang diarahkan pada sebuah mangkuk kaca. Kemudian siswa mengamati apakah cahaya lampu senter dapat menembus mangkuk kaca. Butir soal nomor 3 mengukur keterampilan memprediksi pada materi penguraian cahaya. Pada soal ini siswa diminta untuk memprediksi warna yang akan terlihat ketika sebuah cakram warna diputar dengan cepat. Butir soal nomor 4 mengukur keterampilan menyimpulkan pada materi sifat cermin cembung. Pada soal ini siswa disajikan sebuah ilustrasi peristiwa seorang anak yang dapat melihat bayangan wajahnya pada kaca sepion padahal kaca sepion memiliki ukuran yang lebih kecil dari wajah anak tersebut. Kemudian siswa diminta untuk menyimpulkan peristiwa tersebut sesuai dengan materi yang telah dipelajari. Butir soal nomor 5 mengukur keterampilan mengklasifikasikan pada materi sifat cermin datar. Pada soal ini siswa disajikan pernyataan mengenai sifat-sifat cermin. Kemudian siswa diminta untuk mengklasifikasikan sifat manakah yang termasuk sifat cermin datar. Butir soal nomor 6 mengukur keterampilan memprediksi pada materi pemantulan cahaya. Pada soal ini siswa diminta untuk memprediksi apa yang akan terjadi jika salah satu kaca pada sebuah periskop dihilangkan.

Butir soal nomor 7 mengukur keterampilan mengamati pada materi sifat cermin cembung. Pada soal ini siswa diminta untuk mengamati sebuah cermin yang ada di tikungan jalan. Kemudian siswa diminta untuk mendeskripsikan bayangan yang terbentuk dalam cermin tersebut dan mengapa cermin tersebut dapat membentuk bayangan yang demikian. Butir soal nomor 8 mengukur keterampilan memprediksi pada materi alat optik. Pada soal ini siswa diminta untuk memprediksi yang akan terjadi jika cahaya mengenai sebuah lensa pada kacamata. Butir soal nomor 9 mengukur keterampilan menyimpulkan pada materi penguraian cahaya. Pada soal ini siswa disajikan sebuah ilustrasi peristiwa seorang anak yang melihat pelangi dilangit sesaat setelah hujan turun dan hal yang sama dilihat oleh anak tersebut ketika sedang menyemprotkan air pada tumbuhan di bawah sinar matahari. Kemudian siswa diminta untuk menyimpulkan peristiwa tersebut sesuai dengan materi yang telah dipelajari.

Butir soal nomor 10 mengukur keterampilan mengklasifikasikan pada 
materi pembiasan cahaya. Pada soal ini siswa diminta mengamati dua buah pensil yang dimasukkan ke dalam duah buah gelas. Satu pensil dimasukkan ke dalam gelas berisi air dan satu pensil lagi dimasukkan ke dalam gelas kosong. Kemudian siswa diminta untuk menemukan perbedaan dari kedua bentuk pensil yang ada didalam dua gelas tersebut dan menjelaskan mengapa hal tersebut dapat terjadi. Butir soal nomor 11 mengukur keterampilan mengomunikasikan pada materi sifat cermin cekung. Pada soal ini siswa diminta untuk menjelaskan sifat bayangan yang nampak jika seorang anak meletakkan sebuah gelas sangat dekat dengan bagian cekung sendok makan.

Butir soal nomor 12 mengukur keterampilan mengamati pada materi pemantulan cahaya. Pada soal ini siswa diminta mengamati sebuah gambar seorang anak yang bermain diatas genangan air. Siswa diminta mengungkapkan apa yang terlihat pada genangan air tersebut dan mengapa hal demikian dapat terjadi. Butir soal nomor 13 mengukur keterampilan mengomunikasikan pada materi pembiasan cahaya. Pada soal ini siswa disajikan sebuah ilurstasi peristiwa beberapa orang anak yang masuk ke dalam kolam renang dan mendapati bahwa kolam tidak dangkal seperti yang terlihat dari permukaan. Siswa diminta untuk menjelaskan mengapa hal tersebut dapat terjadi. Butir soal nomor 14 mengukur keterampilan mengklasifikasikan pada materi alat optik. Pada soal ini disajikan beberapa gambar benda. Kemudian siswa diminta mengklasifikasikan dan menjelaskan manakah benda yang termasuk alat optik.

Butir soal nomor 15 mengukur keterampilan mengomunikasikan pada materi pemantulan baur. Pada soal ini siswa diminta untuk menjelaskan bagaimana sebuah ruangan terlihat cukup terang di siang hari padahal lampu dalam ruangan tersebut tidak dinyalakan. Butir soal nomor 16 mengukur keterampilan mengklasifikasikan pada materi cahaya menembus benda bening. Pada soal ini siswa disajikan sebuah ilustrasi peristiwa seseorang yang sedang memilih rumah untuk tempat tinggal. Ada dua pilihan rumah, yang beratap genting dan beratap kaca. Siswa diminta untuk menentukan dan menjelaskan rumah manakah yang lebih baik dijadikan tempat tinggal. Butir soal nomor 17 mengukur keterampilan mengomunikasikan pada materi pemantulan cahaya. Pada soal ini siswa diminta untuk menjelaskan bagaimana semua benda yang ada disekitar kita dapat dilihat oleh mata dengan berbagai warna.

Butir soal nomor 18 mengukur keterampilan menyimpulkan pada materi penguraian cahaya. Pada soal ini disajikan tabel hasil pengamatan terhadap cakram warna dengan diameter serta jari-jari yang berbeda namun menghasilkan warna yang sama ketika diputar dengan cepat. Kemudian siswa diminta untuk menyimpulkan hasil pengamatan tersebut. Butir soal nomor 19 mengukur keterampilan mengamati pada materi alat optik. Pada soal ini siswa diminta mengamati gambar tulisan yang ditutupi dengan kaca pembesar. Kemudian siswa mendeskripsikan bagaimana ukuran huruf yang terkena kaca pembesar tersebut. Butir soal nomor 20 mengukur keterampilan menyimpulkan pada materi sifat cermin datar. Pada soal ini siswa disajikan sebuah ilustrasi peristiwa seorang anak yang bercermin pada cermin hias dan melihat tangan kanannya menjadi tangan kiri pada bayangannya di cermin. Kemudian siswa diminta untuk menyimpulkan jenis cermin yang digunakan pada cermin hias berdasarkan peristiwa tersebut. Pada tahap ini menghasilkan draf 1 yang selanjutnya di revisi terlebih dahulu oleh pembimbing. Versi awal draf I selanjutnya disempurnakan melalui proses pada tahapan pengembangan.

\section{Tahap Pengembangan (Develop)}

Tahap pengembangan dilakukan dengan cara menguji instrumen tes penilaian keterampilan proses sains kepada pakar yang terlibat dalam validasi rancangan yaitu dua dosen ahli dan tiga orang praktisi yaitu guru kelas IV. Hasil dari validasi ini digunakan sebagai bahan 
perbaikan untuk kesempurnaan tes penilaian yang dikembangkan. Dari penilaian pakar diperoleh koreksi, kritik, dan saran yang digunakan sebagai bahan pertimbangan dalam melakukan revisi tes penilaian keterampilan proses sains. Validitas instrumen yang digunakan terhadap tes keterampilan proses sains meliputi validitas isi yang didasari dari hasil validasi oleh pendapat ahli dan praktisi pendidikan untuk pembelajaran IPA kelas IV SD. Para ahli yang terlibat dalam proses validitas isi instrumen tes untuk mengukur keterampilan proses sains antara lain: dua orang dosen dari jurusan pendidikan dasar yaitu Prof. Drs. Sariyasa, M.Sc.,Ph.D dan Dr. I Gede Margunayasa, S.Pd., M.Pd. Selain itu, divalidasi juga oleh 3 orang guru praktisi di bidang pendidikan yang berprofesi sebagai guru sekolah dasar yaitu $\mathrm{Ni}$ Wayan Febriyani Ratnasari, S.Pd, Ni Putu Merti Sulasih, S.Pd, dan Nyoman Widiarsana, S.Pd. Berdasarkan hasil validasi oleh validator selanjutnya dilakukan uji validitas dengan menggunakan analisis CVR. Berdasarkan uji validitas isi dengan CVR diperoleh sebanyak 20 butir soal memiliki nilai CVR $=1,00$ dan ini menandakan bahwa ke- 20 butir soal pada tes penilaian keterampilan proses sains relevan atau valid.

Berdasarkan perhitungan rerata tes penilaian keterampilan proses sains pada aspek materi, konstruksi dan bahasa memiliki kriteria sangat baik yang disajikan dalam Tabel 3.

Tabel 3. Kategori Aspek Materi, Aspek Konstruksi, dan Aspek Bahasa

\begin{tabular}{clcl}
\hline No & \multicolumn{1}{c}{ Aspek } & Rata-rata & Kategori \\
\hline 1 & Aspek Materi & 22,8 & Sangat baik \\
2 & Aspek Konstruksi & 23,2 & Sangat baik \\
3 & Aspek Bahasa & 22,4 & Sangat baik \\
\hline
\end{tabular}

Tabel 3. menyatakan bahwa hasil validasi aspek materi memperoleh ratarata 22,8 berada pada kategori sangat baik, hasil validasi aspek konstruksi memperoleh rata-rata 23,2 berada pada kategori sangat baik, dan hasil validasi aspek bahasa memperoleh rata-rata 22,4 berada pada kategori sangat baik.

Tes penilaian keterampilan proses sains yang dikembangkan sudah sesuai dengan KD serta indikator keterampilan proses sains, dan pertanyaan yang dirancang sudah mengukur keterampilan proses sains dasar seperti mengamati, mengklasifikasikan, memprediksi, menyimpulkan, dan berkomunikasi. Penggunaan tabel dan gambar sudah sesuai. Butir soal tidak bergantung dengan butir soal sebelumnya. Bahasa yang digunakan dalam tes penilaian keterampilan proses sains yang dikembangkan tidak menimbulkan tafsiran ganda atau ambigu. Ada beberapa saran dari validator guna perbaikan tes pada aspek materi, ada beberapa butir soal batasan pertanyaan dan jawaban yang diharapkan masih kurang jelas sehingga perlu diperbaiki. Pada aspek kontruksi, rubrik pedoman penskoran agar lebih menonjolkan keterampilan proses sains, petunjuk umum pengerjaan soal seharusnya diisi rentangan waktu. Sedangkan pada aspek bahasa, penggunaan kalimat agar lebih disederhanakan supaya mudah dipahami siswa. Tes yang sudah direvisi sesuai saran kemudian di uji cobakan pada siswa.

Hasil uji coba dengan sampel sebanyak 50 orang siswa kemudian dianalisis untuk mengetahui validitas butir dan reliabilitas tes. Berdasarkan hasil analisis validitas butir tes penilaian keterampilan proses sains menggunakan rumus korelasi product moment, diperoleh semua butir tes memiliki $r_{\text {hitung }}>r_{\text {tabel }}$ dengan $r_{\text {tabel }}$ sebesar 0,28 sehingga semua butir soal dinyatakan valid. Setelah melaksanakan uji validitas butir, selanjutnya dilakukan uji reliabilitas tes. Hasil perhitungan reliabilitas tes penilaian keterampilan proses sains yang telah diperoleh akan dibandingkan dengan tabel reliabilitas. Analisis reliabilitas tes penilaian keterampilan proses sains menggunakan rumus Alpha-Cronbach 
yang dilakukan dengan menggunakan aplikasi Microsoft Office Excel memperoleh nilai $r_{1.1}$ sebesar 0,93. Data ini menunjukkan reliabilitas berada pada rentang $0,80<r_{1.1} \leq 1,00$ atau berada pada pada kategori derajat reliabilitas sangat tinggi.

Adanya tes penilaian keterampilan proses sains dapat memudahkan guru dalam menilai dan mengetahui keterampilan proses sains yang dimiliki siswa serta dapat melatih keterampilan proses sains dasar siswa yaitu mengamati, mengklasifikasikan, memprediksi, menyimpulkan dan mengkomunikasikan. Selain itu, guru juga memiliki kemampuan dalam merancang instrumen penilaian yang sesuai dengan kompetensi dasar, indikator dan tujuan pembelajaran yang akan dicapai sehingga instrumen yang dibuat dapat mengukur keterampilan proses sains siswa sekaligus pemahaman siswa terkait materi yang dipelajarinya. Tes penilaian keterampilan proses sains yang dikembangkan dapat memberikan informasi kepada guru mengenai keterampilan-keterampilan yang belum atau sudah dikuasai siswa sehingga keterampilan proses sains siswa dapat ditingkatkan. Dalam tes penilaian keterampilan proses sains ini terdapat 20 butir soal berbentuk uraian yang dapat digunakan untuk mengukur keterampilan proses sains siswa, dapat membimbing siswa pada penemuan konsep secara mandiri dan memaksimalkan pemahaman siswa mengenai materi dalam pembelajaran. Untuk memperoleh pengetahuan IPA, yang dilakukan pertama kali oleh siswa adalah mengamati fenomena alam atau mengkaji suatu fakta. Pada saat mengamati atau mengkaji suatu fakta, siswa akan mengalami beberapa proses berpikir, seperti mengindentifikasi dan mengklasifikasi persamaan serta perbedaan yang kemudian memprediksi hal-hal yang akan terjadi, menyimpulkan suatu peristiwa serta mengkomunikasikan sampai akhirnya diperoleh pengetahuan atau konsep IPA tersebut. Keterampilanketerampilan yang dialami siswa dalam proses berpikir merupakan keterampilan proses dasar (Fadiawati,2014). Keterampilan proses dasar bukan merupakan keterampilan bawaan pada siswa sehingga keterampilan tersebut perlu di latih dan dikembangkan dalam proses pembelajaran melalui kegiatan ilmiah dan evaluasi (Mardliya, 2017).

Penelitian ini didukung oleh penelitian Nurhayati (2019) yang menunjukkan bahwa kualitas butir soal yang dikembangkan dapat mengukur keterampilan proses sains siswa pada materi optika, tekanan, dan getaran gelombang pada aspek mengamati, memprediksi, mengukur, mengklasifikasikan, mengomunikasikan, dan menyimpulkan. Kualitas butir soal diperoleh dari analisis telaah ahli dan analisi uji coba didapat hasil validitas atau kelayakan instrumen KPS pada materi optika, tekanan, dan getaran gelombang yang dikembangkan adalah valid dan layak digunakan. Hal tersebut terlihat dari hasil penilaian ahli dari aspek konstruk, materi, dan isi memiliki kategori baik. Validitas butir soal dari instrumen penilaian KPS pada materi optika, tekanan, dan getaran gelombang yang dikembangkan dengan kriteria valid yang berarti soal sudah sahih dalam mengukur kemampuan siswa sesuai indikator. Reliabilitas soal dari instrumen KPS sangat kuat untuk soal pilihan ganda materi optika dan getaran gelombang, reliabilitas kuat untuk soal materi tekanan dan reliabilitas sedang untuk soal essay materi optika, tekanan, dan getaran gelombang. Hal tersebut menunjukkan soal dapat menggambarkan kemampuan siswa pada aspek keterampilan proses sains.

Penelitian yang serupa juga dilakukan oleh Oktaviani (2015) yang menyatakan bahwa instrumen assesmen keterampilan proses sains yang dikembangkan berupa tes tertulis memiliki kriteria sangat tinggi berdasarkan hasil validasi ahli dan tanggapan guru yaitu dengan rata-rata persentase $91,38 \%$ dan $85,27 \%$ pada aspek keterbacaan, konstruksi dan kesesuaian isi materi dengan KD dan indikator KPS. Penelitian Nurtika (2017) menemukan bahwa instrumen yang dikembangkan sebanyak 9 soal uraian dapat mengukur KPS dasar siswa yaitu mengamati, menginferensi, memprediksi, mengklasifikasi, dan mengkomunikasikan. Instrumen asesmen 
ini memiliki tingkat kesesuaian isi materi dengan KD dan indikator KPS sebesar $89,2 \%$, keterbacaan sebesar $84,2 \%$, dan konstruksi sebesar $96,0 \%$ dengankategori sangat tinggi. Berdasarkan uji coba lapangan awal adalah aspek kesesuaian isi materi dengan KD dan indikator KPS sebesar 90,2\%, keterbacaan sebesar $89,2 \%$, dan konstruksi sebesar $86,6 \%$ dengan kategori sangat tinggi. Penelitian Arumsari (2016) juga memperoleh hasil validasi ahli terhadap aspek kesesuaian isi, konstruk, dan keterbacaan, instrumen asesmen sudah valid dengan kategori sangat tinggi. Validitas butir soal instrumen asesmen dominan memiliki validitas soal dengan kategori tinggi, berarti soal sudah sahih dalam mengukur kemampuan peserta didik sesuai indikator serta memiliki reliabilitas soal yang termasuk kategori tinggi.

Hal yang membedakan produk tes pada penelitian ini dengan tes keterampilan proses sains yang sudah ada adalah tes penilaian keterampilan proses sains yang dikembangkan mengukur keterampilan proses sains dasar mengamati, mengklasifikasikan, memprediksi, menyimpulkan dan mengkomunikasikan pada materi sifat-sifat cahaya. Tempat penelitian dan pengembangan tes ini dilakukan pada siswa kelas IV di Gugus VIII I Gusti Ketut Pudja Kecamatan Denpasar Selatan. Untuk tahapan ujicoba soal dilakukan dengan sampel sebanyak 50 orang siswa melalui daring dengan menggunakan google form.

Kelemahan penelitian ini adalah belum terlaksananya tahap penyebaran (disseminate) karena situasi pandemi covid-19 yang tidak memungkinkan peneliti untuk melakukan penyebaran produk tes penilaian keterampilan proses sains. Dalam tahap penyebaran ada beberapa hal yang harus diperhatikan seperti analisis pengguna, menentukan strategi dan tema, pemilihan waktu, serta pemilihan media penyebaran (Thiagarajan, 1974). Sehingga penelitian ini hanya terbatas sampai tahap develop (pengembangan).

\section{PENUTUP}

Berdasarkan hasil penelitian dan pembahasan pengujian dari data dapat disimpulkan bahwa, pengembangan tes penilaian keterampilan proses sains menggunakan model pengembangan mengikuti alur dari Thiagarajan (1974), yaitu menggunakan model 4D yang terdiri dari empat tahapan pengembangan yaitu tahap pendefinisian (define), tahap perancangan (design), tahap pengembangan (develop), dan tahap penyebaran (disseminate). Namun tahap penyebaran (disseminate) tidak dapat dilaksanakan karena kondisi dan situasi pandemi Covid-19. Sehingga pada penelitian ini tahapan yang gunakan hanya 3 tahapan yaitu define, design, dan develop.

Penelitian dan pengembangan ini menghasilkan produk tes penilaian keterampilan proses sains berbentuk soal uraian sebanyak 20 butir soal. Produk tes penilaian terdiri dari kisi-kisi soal, naskah soal dan pedoman penskoran. Berdasarkan analisis data yang telah dilaksanakan dengan pengujian validitas isi menggunakan teknik Lawshe yaitu Content Validity Ratio (CVR) diperoleh sebanyak 20 butir soal memiliki nilai CVR $=1,00$ dan ini menandakan bahwa ke- 20 butir soal pada tes penilaian keterampilan proses sains relevan atau valid. Berdasarkan hasil uji validitas isi dari aspek materi, aspek konstruksi, dan aspek bahasa diperoleh rerata tes penilaian keterampilan proses sains pada masingmasing aspek memiliki kriteria sangat baik. Kemudian berdasarkan hasil uji validitas butir soal tes penilaian keterampilan proses sains yang dilakukan dengan uji coba menggunakan sampel sebanyak 50 orang siswa dengan rumus korelasi product moment diperoleh semua butir tes memiliki $r_{\text {hitung }}>r_{\text {tabel }}$ sehingga semua butir soal dinyatakan valid.

Hasil uji reliabilitas tes penilaian keterampilan proses sains dengan menggunakan rumus Alpha Cronbach memperoleh nilai sebesar 0,93 dengan kategori derajat reliabilitas yang sangat tinggi yang artinya tes yang dikembangkan dapat dikatakan reliabel atau dapat dipercaya untuk digunakan dalam mengukur keterampilan proses sains siswa. 
Dari hasil penelitian dan pengembangan, tes penilaian keterampilan proses sains yang dikembangkan memiliki karakteristik: 1) Tes penilaian keterampilan proses sains berupa tes uraian yang terdiri dari 20 soal; 2) Tes penilaian keterampilan proses sains dirancang khusus dengan soal-soal untuk mengukur keterampilan proses sains dasar siswa yang meliputi keterampilan mengamati, mengklasifikasi, memprediksi, menyimpulkan dan mengkomunikasikan; 3) Tes penilaian keterampilan proses sains yang dikembangkan sudah dilengkapi dengan gambar dan tabel; 4) Bahasa yang digunakan dalam tes penilaian keterampilan proses sains yang dikembangkan mudah dipahami dan tidak menimbulkan tafsiran ganda (ambigu); 5) Penyusunan tes penilaian keterampilan proses sains dilengkapi dengan grand teori, kisi-kisi soal dan pedoman penskoran; 6) Soal yang dikembangkan sudah sesuai dengan aspek dan indikator keterampilan proses sains yang dinilai dan sesuai dengan KD serta materi IPA; 7) Soal yang dikembangkan dapat mengukur indikator keterampilan proses sains sehingga dapat juga dijadikan alat ukur untuk tercapainya tujuan pembelajaran dan dapat memaksimalkan pemahaman siswa mengenai materi dalam pembelajaran IPA.

\section{DAFTAR RUJUKAN}

Adnyana, P.B. dan Citrawathi, D.M. 2017. The Effectiveness of QuestionBased Inquiry Module in Learning Biological Knowledge and Science Process Skills. International Journal ff Environmental \& Science Education. Volume12, No 8,18711878

Arikunto, S. 2010. Prosedur Penelitian Suatu Pendekatan Praktik. Jakarta: Rineka Cipta

Arumsari, T.L. 2016. Pengembangan Instrumen Asesmen Keterampilan Proses Sains Pada Materi Teori Tumbukan. Jurnal Pendidikan dan Pembelajaran Kimia, Volume 5, No.1

Azizah, N.2017. Pengembangan Instrumen Kognitif Keterampilan
Proses Sains Siswa Smp Pada Materi Pesawat Sederhana. Jurnal IImiah Pendidikan Fisika Universitas Lambung Mangkurat, Volume 5, No 3.

BSNP. 2006. Standar Isi 2006 Mata Pelajaran IPA.Jakarta: BSNP

Budiman, A. dan Jailani. 2014. Pengembangan Instrumen Asesmen Higher Order Thinking Skill (HOTS) Pada Mata Pelajaran Matematika SMP Kelas VIII Semester 1. Jurnal Riset Pendidikan Matematika, Volume 1, No. 2, 139-151.

Candiasa, I.M. 2010. Pengujian Instrumen Penelitian Disertai Aplikasi ITEMAN dan BIGSTEPS. Singaraja: Undiksha Press.

Citrawathi, M. 2016. Analisis Kebutuhan Untuk Pengembangan Modul Inkuiri Berbasis Pertanyaan (MIBP) di SMP. Jurnal Pendidikan Indonesia. Volume 5, No 1.

Fadiawati, N. 2014. Ilmu Kimia sebagai Wahana Mengembangkan Si- kap dan Keterampilan Berfikir. Majalah Eduspot Unit Data Base dan Publikasi IImiah FKIP Unila, hal 8-9

IImi, N. 2016. Pengembangan Instrumen Penilaian Keterampilan Proses Sains Pada Pembelajaran Fisika. Ejournal Universitas Negeri Jakarta. Volume 5.

Juanda, A. 2019. Pembelajaran Kurikulum Tematik Terpadu: Teori \& Praktik Pembelajaran Tematik Terpadu Berorientasi Landasan Filosofis, Psikologis dan Pedagogis. Jamblang Cirebon. CV Confident.

Koyan, I. W. 2012. Statistik Pendidikan Teknik Analisis Data Kuantitatif. Singaraja: UNDIKSHA.

Lawshe, C.H. 1975. A quantitative approach to content validity. Personnel psychology, 28, 563-575

Lusidawaty, V. dan Zikri, A. 2020. Pembelajaran IPA Dengan Strategi Pembelajaran Inkuiri Untuk Meningkatkan Keterampilan Proses Sains dan Motivasi Belajar Siswa Di 
Sekolah Dasar. Jurnal Basicedu. Volume 4, No 1, 168-174.

Mania, S. 2014. Asesmen Autentik untuk Pembelajaran Aktif dan Kreatif Implementasi Kurikulum 2013. Makassar: Alauddin Universiy Press.

Mardliya, S. 2017. Pengembangan Instrumen Penilaian Keterampilan Proses Sains Dasar Mata Pelajaran Kimia Pada Kompetisi Dasar Kelarutan Dan Hasil Kali Kelarutan di SMA. Prosiding seminar pendidikan IPA. Palembang. Universitas Sriwijaya

Nurhayati. 2019. Pengembangan Instrumen Tes Keterampilan Proses Sains Pada Materi Fisika Untuk Siswa Sekolah Menengah Pertama. Ejournal IKIP PGRI Pontianak

Nurtika, A., Kadaritna, N., Tania, Lisa. 2017. Pengembangan Instrumen Asesmen Kognitif Berbasis KPS Materi Larutan Elektrolit dan Non Elektrolit. Jurnal Pendidikan dan Pembelajaran Kimia Universitas Lampung

OECD. 2018. PISA 2018 Results (Volume I):What Students Know and Can Do. OECD Publishing, Paris.

Okaviani, E., Fadiawati, N., \& Kadaritna, N. 2015. Pengembangan Instrumen Asesmen Berbasis Ketrampilan Proses Sains pada Materi HukumHukum Dasar Kimia. Jurnal Pendidikan dan Pembelajaran Kimia, Volume 4, No 1, 324-338.
Pamuji, A. G. 2018. Pengaruh Pendekatan Inkuiri Terhadap Sikap IImiah Siswa Kelas 4 Pada Pembelajaran Tematik. Ejournal Undiksha. Volume 3, No 1.

Permendikbud Republik Indonesia Nomor 103 Tahun $2014 \quad$ Tentang Pembelajaran Pada Pendidikan Dasar Dan Pendidikan Menengah.

Sugiyono. 2009. Metode Penelitian Kuantitatif, Kualitatif dan $R$ \& $D$. Bandung: Alfabeta.

Suryani, A., Siahaan, P., dan Samsudin, A. 2015. Pengembangan Instrumen Tes untuk Mengukur Keterampilan Proses Sains SMP pada Materi Gerak. Prosiding Simposium Nasional dan Pembelajaran Sains 2015, Bandung. Hal. 217-220.I

Thiagarajan, S., Doroty, S. S., \& Melvyn, I. S. 1974. Instructional Development for Training Teachers of Exceptional Children. Source Book. Bloominton: Center for Innovation on Theaching the Handicapped.

Trianto. 2010. Model Pembelajaran Terpadu: Konsep, Strategi, dan Implementasinya dalam KTSP. Jakarta : Bumi Aksara

Wati, S. A., Fadiawati, N., dan Tania, L. 2015. Pengembangan Instrumen Asesmen Berbasis Keterampilan Proses Sains pada Bahasan Klasifikasi Materi. Jurnal Pendidikan dan Pembelajaran Kimia, Volume 4, No. 2, 693-707. 